\title{
Lautréamont, I canti di Maldoror
}

\section{Mario Richter}

\section{OpenEdition}

\section{Journals}

\section{Edizione digitale}

URL: http://journals.openedition.org/studifrancesi/3811

DOI: 10.4000/studifrancesi.3811

ISSN: 2421-5856

\section{Editore}

Rosenberg \& Sellier

\section{Edizione cartacea}

Data di pubblicazione: 1 décembre 2012

Paginazione: 596-597

ISSN: 0039-2944

\section{Notizia bibliografica digitale}

Mario Richter, «Lautréamont, / canti di Maldoror», Studi Francesi [Online], 168 (LVI | III) | 2012, online dal 30 novembre 2015, consultato il 05 mars 2021. URL: http://journals.openedition.org/studifrancesi/ 3811 ; DOI: https://doi.org/10.4000/studifrancesi.3811

Questo documento è stato generato automaticamente il 5 mars 2021.

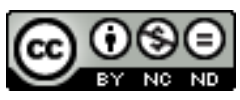

Studi Francesi è distribuita con Licenza Creative Commons Attribuzione - Non commerciale - Non opere derivate 4.0 Internazionale. 


\title{
Lautréamont, I canti di Maldoror
}

\author{
Mario Richter
}

\section{NOTIZIA}

LAUTRÉAMONT, I canti di Maldoror, a cura di Luca SALVATORE, testo originale a fronte, Milano, Arcipelago Edizioni, 2011, pp. 681.

1 La traduzione di un testo come Les Chants de Maldoror ha sempre presentato a chiunque l'abbia voluta intraprendere un problema pressoché irrisolvibile: come rendere nella nostra lingua, al di là di una onesta trasposizione di tipo letterale e di natura sostanzialmente sussidiaria (finora in vario modo praticata), il particolare carattere della prosa di Lautréamont, tutta percorsa da una elaborata ed esperta 'musicalità', che spesso si fa allusiva o ironica nella scelta dei termini e nell'architettura delle frasi? Si tratta di un genere di prosa che conferisce all'opera il suo più peculiare significato $\mathrm{e}$ che indusse il principale promotore del Surrealismo, André Breton, a parlare di «luce nera» o addirittura ad affermare che Maldoror «si fa espressione di una rivelazione totale che sembra andare al di là delle possibilità umane». Con indubbio coraggio e con la più ferma fiducia nelle sue capacità confortate fra l'altro da una solida preparazione filologica e storico-critica, Luca Salvatore ha voluto affrontare l'arduo problema. Non esitando a fare della traduzione una interpretazione, se non proprio un' imitazione (nel senso inteso da Leopardi), è riuscito a consegnare alla nostra sensibilità e alla nostra lingua un testo di grande suggestività, nuovo e intimamente rispettoso dell'originale, fondato su uno scavo linguistico molto scaltro e raffinato. 